\title{
A BRIEF BIOGRAPHY OF FORTUNATO PASQUALINO
}

Fortunato Pasqualino was born in 1923 in Butera, Sicily, an Italian island located west of the southern tip of Italy. Due to family financial need, he worked early in his youth but when the opportunity to study became available, he took private lessons, and this is how he finished high school.

After having served his country in 1942 as a military during World War II, he attended in 1947 the philosophy department at Catania University in Sicily, where he graduated with the doctoral degree (Laurea) in 1951. He taught in Sardegna a few years before accepting in 1949 the invitation by Carlo Carretto to follow him to Rome. Carretto was at that time President of the Gioventù Italiana di Azione Cattolica (Italian Youth for Catholic Action). In 1955, Pasqualino decided to reside permanently in Rome, where he worked for the Italian Television Station RAI (Radio-Televisione Italiana) as a Production Director. He married in 1966 the USborn Barbara Olson, and had four children: Laura Elizabeth, Linda Maria, Dario Luigi, and Francesco Davide.

While in Rome, Pasqualino taught at L'Università Internazionale degli Studi Sociali ProDeo, (The International University for Social Studies ProDeo) as a professor of Philosophy of Entertainment. It was then that the translator of the present book became his student by taking, in 1968, a course in Estetica del Film (Esthetics of the Film). In 1969, Pasqualino founded with his brother Pino a theater company, Teatro di Pupi Siciliani dei Fratelli Pasqualino (Sicilian Puppet Theater of the Pasqualino Brothers), and wrote a play, Abelardo, that earned him the Premio Pescara 
prize. His theater company lasted about thirty years, performing all over Italy. In 2001, UNESCO recognized his literary work for the Puppet Theater as a "masterpiece" of the human intellectual heritage. Pasqualino also contributed to the script of television shows and films, such as the television show Gli Atti Degli Apostoli (The Acts of the Apostles) directed by Roberto Rossellini (1969), and Trionfo, passione e morte del cavaliere della Mancia-Don Chisciotte (Triumph, Passion, and Death of the Horseman of the Mancha - Don Chichotte), which was directed in 1970 by Paolo Gazzara, and the film Durante l'estate (During the Summer), directed by Ermanno Olmi (1971) and shown at the Mostra Internazionale d'Arte Cinematografica de Venezia (International Show of the Cinematographic Art of Venice). In 1975, he received the Teatro Nuovo (New Theater) prize for his Cavallo per la sua maestà (A Horse for His Majesty), and in 1978 he received the Ennio Flaiano prize for his play Socrate Baccante (Socrates the Bacchant) that became a chapter of his published book La danza del filosofo (The Dance of the Philosopher-1992). Lahood translated in 1994 Pasqualino's two-act play Socrate Baccante (Socrates the Bacchant) along with Avicenna's Risālat al Qadar-Essay on Destiny into English as his translation projects for the Master of Fine Arts degree in Literary Translation at the University of Arkansas. A copy of this translation was deposited and registered on May 5, 1997 at the Library of Congress in Washington, DC, USA (PAu2-223190).

Pasqualino published many books and articles, among which are: his doctoral thesis, La necessità di esprimersi (The Necessity of Expressing Oneself-1953), Diario di un Metafisico (Diary of a Metaphysician-1964), Il Giorno che fui Gesù (1977) that was translated into English by Louise Rosier as The Little Jesus of Sicily (1999). In 1996 he published Gli orecchini di Dio (The Earrings of God), also translated and commented on by Lahood (2021). His last book was: Chiunque tu sia. Con Gesù a passo d'asino (Whoever You Are. With Jesus at the Pace of a Donkey-2005). He also contributed articles for various newspapers, including Avvenire (Future), L'Osservatore Romano (The Roman Observer), Famiglia Cristiana (Christian Family), and academic as well as cultural journals such 
as Studi Cattolici (Catholic Studies), and La Fiera Letteraria (The Literary Fair).

Pasqualino passed away in Rome on September 14, 2008. 
